\title{
PENGARUH PENILAIAN KINERJA DAN BONUS TERHADAP KINERJA KARYAWAN PT MEDLINX ASIA TEKNOLOGI JAKARTA
}

\author{
Johan Trihantoro \\ UniSadhuGuna Business School \\ Email: johan.ppim@gmail.com
}

\begin{abstract}
This assessment aims to understand: (1) influence the work on performance employees. (2) influence the bonuses on performance employees. (3) impact assessment of work and the bonuses simultaneously on performance employees of pt medlinx asia technology Jakarta this research be considered in research survey, with instrument of the research.The research by the sample as many as 50 respondents. Technical the analysis used is the linear regression simple and multiple standard significant on $5 \%$.The research on standard significant found that: (1) work assessment influential positive and significant on performance employees of pt medlinx asia technology Jakarta of 4.576 (2) the bonuses influential positive and significantly to employee performance of 5.006 (3) work assessment and a bonus influential positive and significantly to employee performance of $38.533 \sim$.
\end{abstract}

Keywords: assessment; incentive; bonus; employee performance

\section{Pendahuluan}

Perusahaan dalam hal pengembangan kemampuan SDM setiap tahunnya akan memberikan penilaian kinerja (performance appraisal) untuk melihat kualitas dan kinerja karyawan dalam 1 tahun terakhir, Penilaian kinerja diartikan pula sebagai sebuah mekanisme yang baik untuk mengendalikan karyawan. Penilaian kinerja yang dilakukan dengan benar akan bermanfaat bagi karyawan, manajer departeman SDM dan akhirnya bagi perusahaan itu sendiri. Sasaran yang menjadi objek dalam penilaian kinerja adalah kecakapan, kemampuan karyawan dalam melaksanakan suatu pekerjaan atau tugas yang dievaluasi dengan menggunakan tolak ukur tertentu secara objektif dan dilakukan secara berkala.

Penilaian kerja di dalam organisasi atau perusahaan selain untuk menilai hasil kerja karyawan sesuai dengan standar perusahaan, biasanya juga sebagai tolak ukur perusahaan untuk memberikan bonus kepada karyawannya. Bonus tahunan atau gaji ke13 merupakan tambahan uang yang diberikan kepada pekerja selain gaji. Biasanya bonus tahunan diberikan sesuai dengan prestasi dan kemampuan/keuntungan perusahaan di akhir tahun. Maka dari itu pemberian bonus sangat amat penting untuk menunjang kepuasan kinerja pegawai agar produktivitas pegawai semakin baik. Begitu juga dengan memberikan bonus atas kinerja para pegawai akan memberikan timbal balik kontribusi untuk kelangsungan hidup pada organisasi atau perusahaan.

Menurut Hasibuan (2003, h 244) Sumber Daya Manusia adalah kemampuan terpadu dari daya pikir dan daya fisik yang dimikiki individu. Pelaku dan sifatnya 
dilakukan oleh keturunan dan lingkungannya, sedangkan prestasi kerjanya dimotivasi oleh keinginan untuk memenuhi kepuasannya. Sumber Daya Manusia atau man power di singkat SDM merupakan yang dimiliki setiap manusia. SDM terdiri dari daya fikir dan daya fisik setiap manusia. Tegasnya kemampuan setiap manusia ditentukan oleh daya fikir dan daya fisiknya. SDM atau manusia menjadi unsur utama dalam setiap aktivitas yang dilakukan. Peralatan yang handal atau canggih tanpa peran aktif SDM, tidak berarti apa-apa. Daya pikir adalah kecerdasan yang dibawa lahir (modal dasar) sedangkan kecakapan diperoleh dari usaha (belajar dan pelatihan). Kecerdasan tolok ukurnya Intelegence Quotient (IQ) dan Emotion Quality (EQ)

Menurut Mathis dan Jackson (2002) kinerja pegawai adalah mempengaruhi seberapa banyak kontribusi kepada organisasi antara lain termasuk :

1. Kuantitas Kerja

Standar ini dilakukan dengan cara membandingkan antara besarnya volume kerja yang seharusnya (standar kerja norma) dengan kemampuan sebenarnya.

2. Kualitas Kerja

Standar ini menekankan pada mutu kerja yang dihasilkan dibandingkan volume kerja.

3. Pemanfaatan Waktu

Yaitu penggunaan masa kerja yang disesuaikan dengan kebijaksanaan perusahaan.

4. Tingkat Kehadiran

Asumsi yang digunakan dalam standar ini adalah jika kehadiran pegawai di bawah standar kerja yang ditetapkan maka pegawai tersebut tidak akan mampu memberikan kontribusi yang optimal bagi perusahaan.

5. Kerjasama

Keterlibatan seluruh pegawai dalam mencapai target yang ditetapkan akan mempengaruhi keberhasilan bagian yang diawasi. Kerjasama antara pegawai dapat ditingkatkan apabila pimpinan mampu memotivasi pegawai dengan baik berikut:

Menurut Sedarmayanti (2007), tujuan dari penilaian kinerja adalah sebagai

1) Untuk mengetahui keterampilan dan kemampuan pegawai.

2) Sebagai dasar perencanaan bidang kepegawaian khusunya penyempurnaan kondisi kerja, peningkatan mutu dan hasil kerja.

3) Sebagai dasar pengembangan dan pendayagunaan pegawai seoptimal mungkin, sehingga dapat diarahkan jenjang/ rencana karirnya, kenaikan pangkat dan kenaikan jabatan.

4) Mendorong terciptanya hubungan timbal baik yang sehat antara atasan dan bawahan.

5) Mengetahui kondisi organisasi secara keseluruhan dari bidang kepegawaian khususnya kinerja pegawai dalam bekerja.

6) Secara pribadi, pegawai mengetahui kekuatan dan kelemahannya sehingga dapat memacu perkembangannya. Bagi atasan yang menilai akan lebih memperhatikan dan mengenal bawahan dan pegawainya, sehingga dapat lebih memotivasi pegawai.

7) Hasil penilaian pelaksanaan pekerjaan dapat bermanfaat bagi penelitian dan pengembangan di bidang kepegawaian. 
Menurut Hasibuan (2003: 122) sistem dan kebijaksanaan kompensasi terdiri atas:

1. Sistem kompensasi Sistem pembayaran kompensasi yang umumnya diterapkan adalah:

a. Sistem Waktu

Dalam sistem waktu, besarnya kompensasi ditetapkan berdasarkan standart waktu seperti jam, minggu, atau bulan. Administrasi penguupahan sistem waktu relatif mudah serta dapat diterapkan kepada karyawan tetap maupun pekerja harian.

Kebaikan sistem ini adalah administrasi pengupahan mudah dan besarnya kompensasi yang dibayarkan tetap. Kelemahan sistem waktu ialah pekerja yang malas pun kompensasinya tetap dibayar sebesar perjanjian.

b. Sistem Hasil

Dalam sistem hasil, besarnya kompensasi ditetapkan atas kesatuan unit yang dihasilkan pekerja, seperti per potong, Meter, Liter, dan Kilogram.

Kebaikan sistem hasil memberikan kesempatan kepada karyawan yang bekerja bersungguh-sungguh serta berprestasi baik akan memperoleh balas jasa yang lebih besar. Kelemahan sistem ini ialah kualitas barang yang dihasilkan kurang baik dan karyawan yang kurang mampu balas jasanya kecil, sehingga kurang manusiawi.

c. Sistem Borongan

Sistem borongan adalah suatu cara pengupahan yang penetapan besarnya jasanya atas volume pekerjaan dan lama mengerjakannya. Penetapan besarnya balas jasa berdasarkan sistem borongan cukup rumit, lama mengerjakannya, serta banyak alat yang diperlukan untuk menyelesaikannnya. Jadi, dalam sistem borongan pekerja bisa mendapat balas jasa besar atau kecil, tergantung atas kecermatan kalkulasi mereka.

PT Medlinx Asia Teknologi (Medlinx) yang sebelumnya bernama PT Syresnet Internasional merupakan spin off dari PT Sprint Asia Technology (Sprint), yang sejak tahun 2013 memfokuskan diri pada solusi perbankan dan institusi finansial. Seiring dengan kebutuhan dan dinamika perkembangan layanan asuransi kesehatan, pada tahun 2013 Medlinx dibentuk untuk memfokuskan diri menjadi penyedia jasa layanan teknologi informasi bidang Asuransi. Dengan perkembangan teknologi informasi tersebut dan kebutuhan masyarakat serta instansi yang mendorong untuk selalu bergerak dinamis, maka PT Medlinx Asia Teknologi juga mulai merambah ke bisnis asuransi traveling, dimana bisnis traveling juga dihubungkan dengan kebutuhan instansi yang memerlukan asuransi general dan asuransi perjalanan.

kuantitatif dan dalam pengumpulan data, penelitian ini menggunakan pendekatan survey kuesioner sebagai instrument yang disebarkan kepada 50 responden, yang pengolahan datanya menggunakan software SPSS 20.

Menentukan populasi $(\mathrm{N})$ dengan cara menghitung jumlah karyawan PT Medlinx Asia Teknologi dengan tingkat kesalahan (e) sebanyak 10\%. Dari data bulan Januari - Desember 2016 jumlah populasi (N) sebanyak 100 karyawan tingkat kesalahan $10 \%$ maka besarnya sampel adalah :

$\mathrm{n}=100 /\left(1+100 \llbracket(0.1) \rrbracket^{\wedge} 2\right)=47.6=47$ responden (dibulatkan)

Jadi jumlah responden dalam penelitian ini adalah 47-50 orang 


\section{Metode Penelitian}

Metode yang digunakan di dalam penelitian ini adalah metode deskritif kuantitatif dan dalam pengumpulan data, penelitian ini menggunakan pendekatan survey kuesioner sebagai instrument yang disebarkan kepada 50 responden, yang pengolahan datanya menggunakan software SPSS 20.

Menentukan populasi (N) dengan cara menghitung jumlah karyawan PT Medlinx Asia Teknologi dengan tingkat kesalahan (e) sebanyak 10\%. Dari data bulan Januari Desember 2016 jumlah populasi (N) sebanyak 100 karyawan tingkat kesalahan 10\% maka besarnya sampel adalah :

$\mathrm{n}=100 /\left(1+100\left[(0.1) \rrbracket^{\wedge} 2\right)=47.6=47\right.$ responden (dibulatkan)

Jadi jumlah responden dalam penelitian ini adalah 47-50 orang.

\section{Hasil dan Pembahasan}

1. Uji Validitas

Tabel 1 Uji Validitas Variabel Penilaian Kerja (X1)

\begin{tabular}{cccl}
\hline \multirow{2}{*}{ Pernyataan } & \multicolumn{3}{c}{ Penilaian Kerja (X1) } \\
\cline { 2 - 4 } & $\mathbf{r}$ & $\begin{array}{c}\mathbf{r}_{\text {tabel }} \\
\mathbf{n i t u n g}=\mathbf{5 0}\end{array}$ & Keterangan \\
\hline 1 & 0,512 & 0,279 & Valid \\
\hline 2 & 0,416 & 0,279 & Valid \\
\hline 3 & 0,801 & 0,279 & Valid \\
\hline 4 & 0,618 & 0,279 & Valid \\
\hline
\end{tabular}

Berdasarkan tabel 1, dapat dilihat bahwa untuk masing-masing pernyataan pada variabel Kompensasi (X1) seluruh instrumen dapat dikatakan valid, karena nilai rhitung yang dihasilkan jauh lebih besar dari pada nilai rtabel yang ada untuk $\mathrm{n}=50$ (lima puluh) yaitu 0,279.

Tabel 2 Uji Validitas Variabel Bonus (X2)

\begin{tabular}{cccl}
\hline \multirow{2}{*}{ Pernyataan } & \multicolumn{3}{c}{ Bonus (X2) } \\
\cline { 2 - 4 } & $\mathbf{r}_{\text {hitung }}$ & $\begin{array}{c}\mathbf{r}_{\text {tabel }} \\
\mathbf{5} \mathbf{5 0}\end{array}$ & Keterangan \\
\hline 1 & 0,715 & 0,279 & Valid \\
\hline 2 & 0,785 & 0,279 & Valid \\
\hline 3 & 0,845 & 0,279 & Valid \\
\hline
\end{tabular}

Berdasarkan tabel 2, dapat dilihat bahwa untuk masing-masing pernyataan pada variabel Pengembangan Karir (X2) seluruh instrumen dapat dikatakan valid, karena nilai rhitung yang dihasilkan jauh lebih besar dari pada nilai rtabel yang ada untuk $\mathrm{n}=50$ (lima puluh) yaitu 0,279. 


Tabel 3 Uji Validitas kinerja karyawan $(\mathbf{Y})$
\begin{tabular}{|ccll}
\multirow{3}{*}{ Pernyataan } & \multicolumn{3}{c}{ kinerja karyawan $(\mathbf{Y})$} \\
\cline { 2 - 4 } & $\begin{array}{c}\mathbf{r} \\
\text { hitung }\end{array}$ & $\begin{array}{c}\mathbf{r} \text { tabel } \\
\mathbf{n}=\mathbf{5 0}\end{array}$ & Keterangan \\
\hline 1 & 0,202 & 0,279 & Tidak Valid \\
\hline 2 & 0,484 & 0,279 & Valid \\
\hline 3 & 0,163 & 0,279 & Tidak Valid \\
\hline 4 & 0,599 & 0,279 & Valid \\
\hline 5 & 0,607 & 0,279 & Valid \\
\hline 6 & 0,354 & 0,279 & Valid \\
\hline 7 & 0,441 & 0,279 & Valid \\
\hline
\end{tabular}

Berdasarkan tabel di atas, dapat dilihat bahwa untuk masing-masing pernyataan pada variabel Kinerja Karyawan (Y) seluruh instrumen dapat dikatakan valid, karena nilai rhitung yang dihasilkan jauh lebih besar dari pada nilai rtabel yang ada untuk $\mathrm{n}$ $=50$ (lima puluh) yaitu 0,279 .

2. Uji Reliabiltas

Tabel 4 Uji Reabilitas Variabel Penilaian Kerja (X1)

\begin{tabular}{cc}
\hline Cronbach's alpha & N of item \\
\hline 402 & 4 \\
\hline
\end{tabular}

Berdasarkan tabel 4, untuk uji reabilitas variabel Kompensasi (X1) dengan nilai Cronbach's Alpha sebesar 0,402 sehingga dapat disimpulkan instrumen penelitian mengenai variabel Kompensasi (X1).

Tabel 5 Uji Reabilitas Variabel Kinerja Karyawan

\begin{tabular}{ll}
\hline \multicolumn{2}{c}{ Reliability Statistics } \\
\hline Cronbach's \\
Alpha & N of Items \\
\hline 399 & 5 \\
\hline
\end{tabular}

Berdasarkan tabel 5, untuk uji reabilitas variabel Kinerja Karyawan (Y) dengan nilai Cronbach's Alpha sebesar 0,399 sehingga dapat disimpulkan instrumen penelitian mengenai variabel Kinerja Karyawan (Y) adalah Reliable dengan kriteria sangat tinggi.

3. Uji Normalitas

\section{Tabel 6 Hasil Uji Normalitas Data}

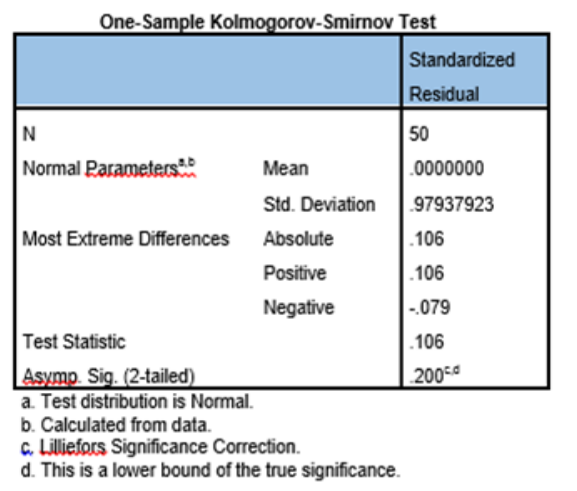


Berdasarkan tabel 6, nilai signifikansi (2-tailed) sebesar 0.200, dapat diartikan bahwa nilai signifikansi (2-tailed) alat ukur tersebut berada di atas 0.05 sehingga data dikatakan berdistribusi normal. Sedangkan nilai KolmogorovSmirnov / Test Statistic sebesar 0.106, berarti data residual terdistribusi normal.

4. Analisis Regresi Linier Beganda (multiple)

Tabel 7 Hasil analisis Regresi Linier Berganda

\begin{tabular}{|c|c|c|c|c|c|c|c|}
\hline & \multirow[t]{2}{*}{ Model } & \multicolumn{2}{|c|}{$\begin{array}{c}\text { Unstandardized } \\
\text { Coefficients }\end{array}$} & \multirow{2}{*}{$\mathrm{t}$} & \multirow{2}{*}{ Sig. } & \multicolumn{2}{|c|}{$\begin{array}{c}\text { Collinearity } \\
\text { Statistics } \\
\end{array}$} \\
\hline & & B & $\begin{array}{l}\text { Std. } \\
\text { Error }\end{array}$ & & & $\begin{array}{l}\text { Toler } \\
\text { ance }\end{array}$ & VIF \\
\hline \multirow[t]{3}{*}{1} & (Constant) & 14.736 & 2.162 & 6.815 & .000 & & \\
\hline & $\mathrm{X} 1$ & .407 & .130 & 3.130 & .003 & .993 & 1.007 \\
\hline & $\mathrm{X} 2$ & .668 & .102 & 6.516 & .000 & .993 & 1.007 \\
\hline
\end{tabular}

Analisis regresi linier berganda digunakan untuk mengukur kekuatan hubungan antara dua variabel atau lebih. Model regresi yang digunakan dalam penelitian ini adalah sebagai berikut:

$$
\mathrm{Y}=\mathrm{a}+\mathrm{b} 1 \mathrm{X} 1+\mathrm{b} 2 \mathrm{X} 2+\sum
$$

Keterangan:

$\mathrm{Y}=$ Kinerja Karyawan

$\mathrm{a}=$ Bilangan Konstanta

b1 $=$ Koefisien regresi variabel Penilaian Kerja

b2 = Koefisien regresi variabel Bonus

$\sum=$ Standar error

$\mathrm{X} 1=$ Penilaian Kerja

$\mathrm{X} 2=$ Bonus

Untuk menentukan nilai persamaan regresi linear bergandanya sebagai berikut: $\mathrm{Y}=14.736+0.407 \mathrm{X} 1+0.668 \mathrm{X} 2+\sum$. Dapat dijelaskan sebagai berikut:

a. Nilai konstanta intersep sebesar 14,736 menyatakan bahwa jika variabel Kompensasi (X1), variabel Pengembangan Karir (X2) tetap (tidak mengalami perubahan) maka nilai variabel Kinerja Karyawan (Y) akan meningkat sebesar 14,736. Nilai koefisien regresi variabel Kompensasi (X1) terhadap variabel Kinerja Karyawan (Y) adalah sebesar 0.407. Hal ini berarti jika variabel Kompensasi (X1) naik 1 satuan akan meningkatkan variabel Kinerja Karyawan (Y) sebesar 0.407, dengan asumsi variabel Pengembangan Karir (X2) dan konstanta dianggap konstan.

b. Nilai koefisien regresi variabel Pengembangan Karir (X2) terhadap variabel Kinerja Karyawan (Y) adalah sebesar 0.668. Hal ini berarti jika variabel Pengembangan Karir (X2) naik 1 satuan akan meningkatkan variabel kinerja karyawan (Y) sebesar 0.668, dengan asumsi variabel Kompensasi (X1) dianggap konstan. 


\section{Uji T}

a. Hubungan Variabel Penilaian Kerja (X1) dengan Kinerja Karyawan (Y)

Jika diperhatikan hasil tabel coefficients di atas dengan menggunakan perhitungan analisis SPSS Versi 22, maka nilai thitung untuk variabel X1 (Penilaian Kerja) sebesar 3.130, sedangkan nilai ttabel untuk $\mathrm{n}=50$ sebesar 2.009. Jadi $3.130>2.009$, dapat disimpulkan bahwa secara parsial variabel Penilaian Kerja (X1) berkorelasi terhadap Kinerja Karyawan (Y).

b. Hubungan Variabel Pemberian bonus (X2) dengan Kinerja Karyawan (Y)

Jika diperhatikan hasil tabel coefficients di atas dengan menggunakan perhitungan analisis SPSS Versi 22, maka nilai thitung untuk variabel X2 (Pengembangan Karir) sebesar 3.130, sedangkan nilai ttabel untuk n $=50$ sebesar 2.009. Jadi, $3.130>2.009$, dapat disimpulkan bahwa secara parsial variabel Pemberian Bonus (X2) berkorelasi terhadap kinerja karyawan (Y). signifikan sebesar 0,000 karena 0,000 <0,05, maka dap at dikatakan Kompensasi (X1) dan Pemberian Bonus (X2) secara bersama-sama mampu menjelaskan Kinerja Karyawan (Y) pada $\alpha=5 \%$

c. Uji Multikolinearitas

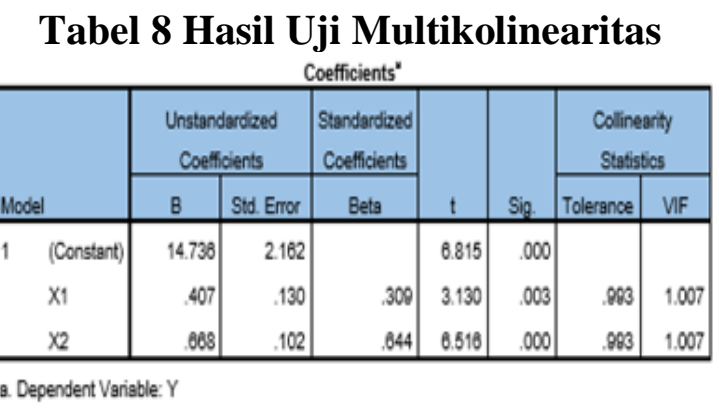

Berdasarkan tabel 8, dapat diketahui bahwa nilai Variance Inflation Factor (VIF) dari masing-masing variabel independent tidak memiliki nilai yang lebih dari 10,00 sehingga dapat disimpulkan bahwa model regresi dalam penelitian ini tidak mengandung multikolinieritas.

6. Uji Anova (F)

Tabel 9 Hasil Uji Anova (F)

\begin{tabular}{|c|c|c|c|c|c|c|}
\hline & Model & Sum ol Squares & df & Mean Square & F & Sig. \\
\hline \multirow[t]{3}{*}{1} & Regression & 121.865 & 2 & 60.932 & 28.034 & $.000^{\circ}$ \\
\hline & Residual & 102155 & 47 & 2174 & & \\
\hline & Total & 224.020 & 49 & & & \\
\hline
\end{tabular}

Dari hasil uji ANOVA atau fhitung didapat nilai fhitung sebesar 28.034 dimana lebih besar dari nilai ftabel untuk $n=50$ sebesar 3.18 atau $28.034>3.18$ dengan 
tingkat signifikan sebesar 0,000 karena $0,000<0,05$, maka dap at dikatakan Kompensasi (X1) dan Pemberian Bonus (X2) secara bersama-sama mampu menjelaskan Kinerja Karyawan (Y) pada $\alpha=5 \%$

7. Uji Multikolinearitas

Tabel 10 Hasil Uji Multikolinieritas

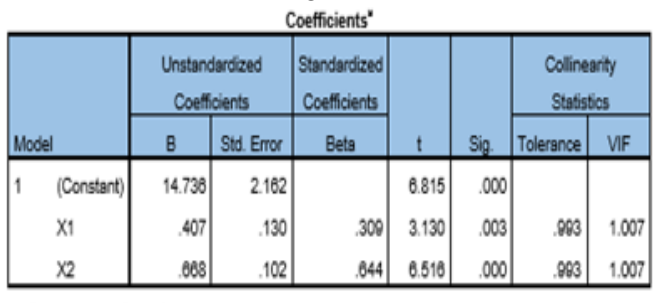

8. Dependent Varisble: $Y$

Berdasarkan tabel di atas, dapat diketahui bahwa nilai Variance Inflation Factor (VIF) dari masing-masing variabel independent tidak memiliki nilai yang lebih dari 10,00 sehingga dapat disimpulkan bahwa model regresi dalam penelitian ini tidak mengandung multikolinieritas.

8. Uji Heteroskedastisitas

Tabel 11 Hasil Uji Heteroskedastisitas

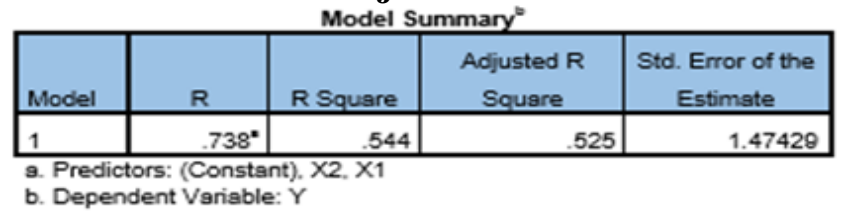

Berdasarkan pada tabel 11 yakni Model Summary yang menghasilkan nilai $\mathrm{R}$ Square sebesar 0.544, artinya bahwa Kompensasi dan Pengembangan Karir secara bersama-sama mapu menjelaskan variabel Kinerja Karyawan sebesar $60.2 \%$ sedangkan sisanya sebesar $39.8 \%$ adalah faktor-faktor lain yang tidak diteliti dalam penelitian ini.

9. Uji Heteroskedastisitas

Tabel 12 Hasil Uji Heteroskedastisitas

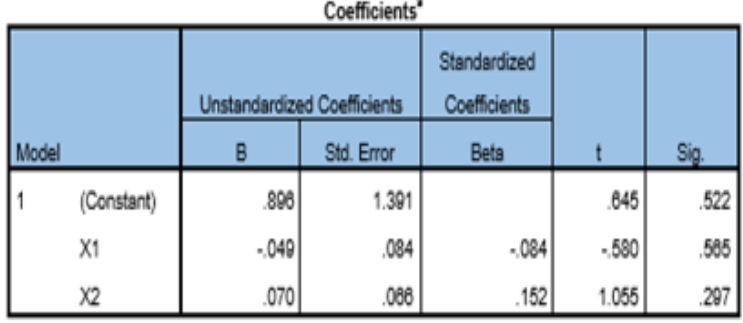

a. Dependent Variable: ABRES

Dalam penelitian ini, untuk mendeteksi gejala heteroskedastisitas di dalam model menggunakan metode Glejser. Hasilnya seperti tabel di atas. Tingkat signifikan masing-masing variabel X1 dan X2 berada di atas 0.05. Hal ini menjelaskan bahwa di dalam model tidak terdapat gejala heteroskedastisitas atau dengan kata lain model homoskedastisitas. 
10. Uji Linearitas

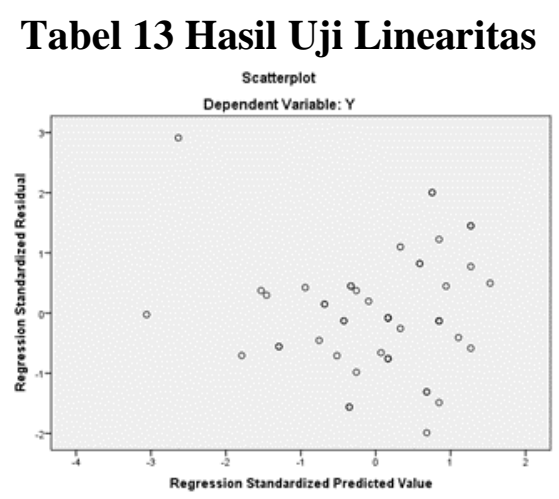

Berdasarkan gambar diatas dapat diketahui bahwa hasil pengujian linearitas diatas menunjukan penyebaran data (tidak terjadi penumpukan data pada bagian tertentu) sehingga dapat di simpulkan regresi yang digunakan adalah regresi linear

\section{Kesimpulan}

Terdapat pengaruh parsial dari penilaian kerja terhadap kinerja karyawan. Hal tersebut dapat dilihat dari thitung untuk variabel X1 (Penilaian Kerja) sebesar 4.576, sedangkan nilai ttabel untuk $\mathrm{n}=50$ sebesar 2.009. Jadi $4.576>2.009$, dapat disimpulkan bahwa secara parsial variabel penilaian kerja (X1) berkorelasi positif signifikan terhadap kinerja karyawan (Y) pada $\alpha=5 \%$.

Terdapat pengaruh parsial dari pemberian bonus terhadap kinerja karyawan Hal ini dapat dilihat dari nilai thitung untuk variabel X2 (Pemberian Bonus) sebesar 5.006, sedangkan nilai ttabel untuk $n=50$ sebesar 2.009. Jadi $5.006>2.009$, dapat disimpulkan bahwa secara parsial variabel pemberian bonus (X2) berkorelasi positif signifikan terhadap kinerja karyawan (Y) pada $\alpha=5 \%$.

Terdapat pengaruh simultan dari Penilaian Kerja dan Pemberian Bonus terhadap Kinerja Karyawan. Hal tersebut dapat kita lihat dari nilai fhitung sebesar 38.533, sedangkan nilai ftabel untuk $\mathrm{n}=50$ sebesar 3.18. Jadi $38.533>3.18$, dapat disimpulkan bahwa kualitas informasi dan sistem informasi manajemen secara bersama-sama atau secara simultan berkorelasi dengan kinerja karyawan (Y) pada $\alpha$ $=5 \%$. 


\section{DAFTAR PUSTAKA}

Sudarmanto. (2014). Kinerja dan pengembangan Kompetensi SDM Teori, Dimensi Pengukuran, dan Implementasi dalam Organisasi. Jakarta: Pustaka Pelajar

Priyatno, Duwi. (2013). Mandiri Belajar Analisis Data Dengan SPSS. Yogyakarta: Andi

Mathis, Robert L dan John H Jackson. (2012). Manajemen Sumber Daya Manusia Edisi Revisi. Jakarta: Bumi Aksara.

Priyatno, Duwi. (2014). SPSS 22 Pengolah Data Terpraktis (Edisi 1). Yogyakarta: Andi.

Richard L, Daft. (2017). Era Baru Manajemen New Era of Manajemen (Edisi Kesembilan). Jakarta: Salemba Empat.

Rahayu, .Wiwiet. (2015). Pengaruh Kompensasi Terhadap Kinerja Karyawan PT Imako Perkasa Lines. Skripsi di FISIP Balikpapan

Rivai, Veitzal. (2013). Manajemen Sumber Daya Manusia Untuk Perusahaan. Jakarta: Raja Grafindo Persada.

Robbins, Stephen P. dan Coulter, Mary. (2012). Manajemen (Edisi Kesebelas). Jakarta: Erlangga

Suryani, Ratna. (2015). Pengaruh Kompensasi dan Motivasi Terhadap Kinerja Karyawan pada PT Liebra Permana. Skripsi di Universitas Pasundan.

Sutrisno, Edy. (2015). Manajemen Sumber Daya Manusia. Jakarta: Kencana.

Yamin, Sofyan. (2014). SPSS Complete Teknik Analisis Terlengkap dengan Software SPSS. Jakarta: Salemba Infotek.

Dito, A. H. (2010). Pengaruh Kompensasi Terhadap Kinerja Karyawan Dengan Motivasi Kerja Sebagai Variabel Intervening. Skripsi Universitas Diponegoro: Semarang.

Feriyanto, Andri dan Endang Shynta Triana. (2015). Pengantar Manajemen (3 in 1). Kebumen: Mediatera

Ghozali, Imam. (2013). Analisis Multivariat Dengan Program SPSS. Semarang: BP Undip

Ghozali, Imam. (2016). Aplikasi Analisis Multivariat Dengan Program IBM SPSS (Edisi Kedepalan). Semarang: Universitas Diponegoro

Hadi Saputra, Imam. (2015). Pengantar Manajemen Umum. Jakarta: Gunadarma 
Handoko, T. Hani. (2010). Manajemen Personalia dan Sumberdaya Manusia Edisi ke2. Yogyakarta: Penerbit BPFE

Hasibuan, S. P. Melayu. (2014). Manajemen Sumber Daya Manusia, Edisi Revisi. Jakarta: Penerbit PT Bumi Aksara

Hudiwinarsih, Murty. (2015). Pengaruh Kompensasi, Motivasi, dan Komitmen Organisasi Terhadap Kinerja Karyawan.

Hosra Afrizoni. (2015). Kompensasi dan Kompetensi dalam Peningkatan Kinerja Pegawai. Tesis di Universitas Widyatama Bandung.

Kusuma. (2015). The Effect Compensation, Work Environmet, and Motivation On The Performance of Employees At PT COCA COLA BOTTLING Central Java

Kusuma, A. A. dan Dwi, W.P.S.N. (2012). Pengaruh Kompensasi, Lingkungan Kerja, dan Motivasi Terhadap Kinerja Karyawan. Jurnal Mahasiswa QMAN.

Mangkunegara, AA, Anwar, Prabu. (2013). Manajemen Sumber Daya Manusia Perusahaan. Bandung: PT Remaja Roskadakarya.

Mangkuprawira, Sjafitri. (2011). Manajemen Sumber Daya Manusia Strategik Edisi ke2. Bogor: Penerbit Ghalia Indonesia 